\title{
What drives ICT clustering in European Cities?
}

\section{Article}

Accepted Version

Belitski, M. and Desai, S. (2016) What drives ICT clustering in European Cities? Journal of Technology Transfer, 41 (3). pp. 430-450. ISSN 1573-7047 doi: https://doi.org/10.1007/s10961015-9422-y Available at https://centaur.reading.ac.uk/43285/

It is advisable to refer to the publisher's version if you intend to cite from the work. See Guidance on citing.

To link to this article DOI: http://dx.doi.org/10.1007/s10961-015-9422-y

Publisher: Springer

All outputs in CentAUR are protected by Intellectual Property Rights law, including copyright law. Copyright and IPR is retained by the creators or other copyright holders. Terms and conditions for use of this material are defined in the End User Agreement.

\section{www.reading.ac.uk/centaur}

\section{CentAUR}

Central Archive at the University of Reading

Reading's research outputs online 


\title{
What Drives ICT Clustering in European Cities?
}

\author{
Maksim Belitski \\ Henley Business School, University of Reading \\ Whiteknights, Reading, RG6 6UR \\ Email: $\underline{\text { m.belitski@ reading.ac.uk }}$ \\ Sameeksha Desai \\ School of Public and Environmental Affairs, Indiana University \\ 1315 E. $10^{\text {th }}$ Street, Bloomington, IN 47405, USA \\ E-mail: desai@indiana.edu
}

\begin{abstract}
ICT clusters have attracted much attention because of their rapid growth and their value to other economic activities. We examine the drivers of ICT activity in 227 cities across 22 European countries. We examine the national business environment along with city-level factors to identify important factors which influence ICT clustering. We address interdependencies at different levels using a nested multilevel model, which assesses the impact of urban characteristics and country conditions on ICT clustering. We also examine two types of ICT activities, products and content. Our results demonstrate idiosyncratic impacts based on national business environment and urban factors on ICT clustering, and further, that the impacts vary depending on the nature of the ICT activity.
\end{abstract}

Keywords: ICT, clustering, Europe, policy, multi-level, urban

Acknowledgements: We are grateful to Zoltan Acs, David Audretsch and participants of the 2013 Transatlantic Policy Consortium for comments. 


\section{Introduction}

Recent policymaking in Europe has focused on fueling economic growth as well as supporting skill and employment creation, with a strong emphasis on technology and the information and communication technologies (ICT) sector (LEAD, 2014). SMEs, including new businesses, are at the heart of innovative activities in ICT, and play a vital role in generating new ideas and quickly transforming these ideas into technology and assets (European Commission, 2012). Recent competitiveness policies embraced by European policymakers specifically target startups, $\mathrm{R} \& \mathrm{D}$ and product innovation in the ICT sector (European Commission, 2012).

Technological advancements in information technologies can support and create opportunities for new firms, as well as prompt spillover into other industries reliant on technologies and eskills (Siegel, 2006; LEAD, 2014). In addition, these types of products and technologies may themselves generate innovation, further improving market opportunities and welfare (Holmen and McKelvey, 2005; Bell and Pavitt, 1993). This virtuous circle is of great interest for policymakers. Indeed, ICT investment has been linked to productivity growth (Iammarino and Jona-Lasinio, 2013; Vu, 2011; Jorgenson and Stiroh, 2000) and ICT firms more broadly with economic growth across a range of countries (Leitao and Baptista, 2011, 2008), the OECD countries (Iammarino and Jona-Lasinio, 2013) and specifically in Europe (LEAD, 2014).

Clustering has been linked with knowledge spillovers and boosting regional competitiveness (Audretsch and Keilbach, 2007; Audretsch and Feldman, 1996). In particular, ICT clustering has been used to support regional economic growth and technology-based development in European regions (Bilbao-Osorio and Rodríguez-Pose, 2004; McCann and Ortega-Argilés, 2013).

The drivers of ICT clusters are thus of great importance from a scholarly and policy perspective (Brenner, 2004; Krugman, 1991). Research on the economic geography of innovation asks why these clusters exist, how they emerge and why they succeed in various locations (Brenner and Mühlig, 2013). Many studies have addressed the question of clustering as well as spatial and industry drivers (Porter, 1990; Saxenian, 1994; Druilhe and Garnsey, 2000; Bresnahan et al. 2001; Van der Linde 2003; Breznitz, 2007), but investigation into both local (regional or urban) and national (country) conditions remains necessary. In particular, different "levels" may be relevant in explaining ICT clustering.

Our paper connects national institutional (regulatory) conditions with local (urban) conditions to explain ICT clustering in European cities. Europe as a region has embraced innovation and ICT clustering, and its cities are important centers for economic production as the region as whole has become increasingly borderless. We use panel data on 227 cities in 22 European countries over the period 2004-2009. Our analysis is a nested multi-level approach, which allows us to incorporate both the national and urban levels. At the country level, we consider both the time cost and monetary cost of three types of regulatory policies (starting a business, registering property, enforcing contracts). At the city level, we consider local access to universities and knowledge facilities, and enterprise density networks. Our findings indicate that

We make at least two contributions to the extant literature. First, we make a conceptual contribution by considering both national and urban context in ICT clustering. Understanding 
sub-national dimensions of ICT clustering is a neglected question (Breznitz, 2007; Iammarino and Jona-Lasinio, 2013) and we are able to provide insight on this question specifically. We also consider heterogeneity in both the national and urban context, and include several different, reflective dimensions. Second, we make a methodological contribution by using a nested multilevel framework. The literature which examines the drivers of clustering and firm formation has focused on the national (Chavis et al., 2011; Acs et al., 2008; Sobel, 2008; Manolova et al., 2008; Klapper et al., 2006) or the local level (Woolley and Rottner, 2008; Glaeser et. al., 2010; Woolley, 2013; Acs et. al., 2013), but not both together. We address the need for multi-level research on questions related to new firm formation and external business environment and institutions (see Payne et al., 2013; Estrin et. al., 2013; Beckman et al., 2012; Zahra and Wright, 2011; Bruton et al., 2010; Phan and Foo, 2004).

Our paper proceeds as follows: Next, we provide a brief overview of two types of ICT clustering. In the third section, we present our theoretical foundation and hypotheses, followed by our method in the fourth section. We discuss results in the fourth section, followed by conclusion.

\section{ICT clustering}

An important consideration in our study is the heterogeneity of outcome (Wiklund et al., 2011). Questions related to ICT clustering are not new (e.g., Porter, 1990; Saxenian, 1994; Druilhe and Garnsey, 2000; Van der Linde 2003; Breznitz, 2007; Brenner and Mühlig, 2013), but there remain gaps in understanding different types of ICT activities are related. Heterogeneity in firms producing different kinds of ICT outputs has been observed since the rapid development growth of digital technologies and e-skills (LEAD, 2014). Some current policy-oriented projects aim to understand how to better leverage different types of ICT activities, such as the LEAD project which embeds ICT products and ICT contents in the new EU growth digital strategy (LEAD, 2014).

We are interested not only in ICT clustering, but we are interested to see if the type of economic activity undertaken by ICT firms matters. We therefore distinguish between two types of ICT activities: ICT products and ICT content. The distinction between ICT content and ICT product firms is identified based on the nature of the activities they undertake, and are introduced by the European Commission in the ICT Technologies Work Program 2013 (European Commission, 2012) and Innovation Observatory reports (Innovation Observatory, 2013).

ICT product manufacturers are firms that introduce ICT content to the market and commercialize $i t$, such as videoconferencing and video-calling Apps; Internet-based VoIP (e.g., Skype, Fring, Viber); unified communications; online office applications (e.g., Microsoft Office 2010, Windows 8 or Google Docs); online collaboration applications (e.g., Microsoft Lync or SharePoint, or Cisco WebEx or Google Apps); personal computers and tablet computers; IT security service package for network connections or applications; broadband connections devices and appliances based on fibre (Innovation Observatory, 2013). Firms producing ICT content also known as a digital content (Mullan, 2011; Villasenor, 2013) are companies where new enabling capabilities and applications are emerging, including Internet and cloud computing technologies, developments and applications; Micro- and nano-electronics which connects more devices to the cloud; interfaces such as touch screens and various interaction modes with 
computers; intelligent environments e.g. web-based social networking, making use of adaptive, learning, cognitive and bio-inspired systems (European Commission, 2012). Examples also include: video content e.g. home videos, music videos, TV shows, and movies; software and freeware, e.g. computer software such as Mizilla and operating systems such as Apple's OS X Mavericks; audio and music over the Internet or from their computer desktop. Digital content in the form of music is also available through Pandora and last.fm, which allow listeners to listen to music online. Photo and image sharing is another example of digital content (e.g, Instagram), as is popular instant messaging platform WhatsApp. The distribution of ICT product and ICT content firms in our sample is shown in Appendix A.

\section{Country business environment, local urban context and ICT clustering}

ICT firms, like firms in the other industries, must operate within multilevel constraints, taking into account both regional and national business environment (Acs et. al., 2013; Szerb et. al., 2013). ICT firms in cities are embedded into a local context while also following national regulatory requirements, with institutions affecting allocation of the ICT firms (European Commission, 2011). This study therefore draws on a mixed multilevel approach, and estimates the impact of both national and urban factors on ICT firms clustering.

Several studies found that national public policy, culture and infrastructure may propel ICT firms differently (Breznitz, 2007). For example, the HTP framework (Breznitz, 2007) targets specific industries to encourage private firms and develop new capabilities in greater $R \& D$ and innovation routines and technologies. Such policies target various levels of ICT firm formation and development. With respect to country context, policymakers generally embrace a "less is better" approach ${ }^{1}$, yet the true impact of specific institutions policies is not fully understood (Estrin et. al., 2013). In fact, the business environment is increasingly conceived of as a heterogeneous phenomenon (Stenholm et al., 2013; Chavis et al., 2011) and we treat it as such to disentangle effects. It is intuitive that higher costs (financial or otherwise) to comply with regulations would have a negative impact on firms (Klapper et al., 2006; Desai et al., 2013).

The nature of technology (Garud and Karnøe, 2003; Stuart and Sorenson, 2003) itself can provide some insight on responsiveness of ICT firms to changes in regulation. ICT product firms manufacture goods like hardware and computers, which require engineering capacity, technology and are capital-intensive. Such firms are likely to be sensitive to national regulatory changes due to embeddedness of financial, physical and capital resources (Szerb et. al., 2013). ICT content firms make digital content, which needs to be highly integrated with the national regulatory system. Changes in regulation, which affect ICT content firms directly or their clients, can decrease their flexibility and mobility. Firms which specialize in software design and consultancy need to develop country-specific algorithms of competencies and adapt to the national informatics infrastructure and the regulations which govern it. Both types of ICT clustering thus are likely to be affected by national regulatory conditions, but ICT product firms ICT content firms could be affected differently. Given the nature of entry barriers in the ICT

\footnotetext{
${ }^{1}$ For example, a European Commission report noting that initiatives on licensing procedures are "based on the assumption that simplification in licensing procedures leads to the creation of more firms (2011: Introduction).
} 
sector, ICT product firms are expected to be less affected by changes in national regulatory conditions than digital content manufacturers (LEAD, 2014). ICT products like computers may be standardized across countries in terms of features and market policies, such as computers and notebooks, whereas digital content may vary significantly within and across countries. We therefore hypothesize:

\section{HI: National regulatory conditions will affect both ICT product clustering and ICT content clustering, and the effect will be stronger for ICT content clustering.}

Both national and regional conditions are important in explaining firm clustering (Porter, 1990, 1998), including access to a qualified labour force, availability of capital, physical infrastructure, complimentary industries and access to knowledge. The need for human capital and knowledge in supporting technology-driven industries is well-established. This can be enhanced by close university-business relationships, which can sprout from geographic proximity to local universities and research centres. Universities facilitate human capital formation and can boost the supply of highly-educated employees and interns in the ICT sector. In addition, universities can create an environment conducive to the development, exploration and validation of new ideas. Universities can also amplify resources available to firms by lowering the cost of highskill labor through a labor pooling effect. Technology firms can create opportunities which expand technology sectors, and in doing so, can also create opportunities for more linkages with universities (Siegel, 2006; Druilhe and Garnsey, 2000)

Proximity to good universities and the intensity of collaboration with institutions of higher education facilitates the allocation of entrepreneurial efforts towards technology and techintensive activity (Stenholm et. al., 2013). Access to universities can also increase the potential for knowledge spillovers (Audretsch and Feldman, 1996; Audretsch and Lehnmann, 2005). In terms of technology commercialization, firms often collaborate with universities, nonprofits and private research foundations (Shan, Walker and Kogut, 1994), allowing for the pursuit of different research agendas. When partnering with universities, large ICT firms have been found to focus on breakthrough innovations with specific commercial applications (Hoang and Rothaermel, 2010). This could mean the effect of universities on ICT product firms and ICT content is nuanced. ICT product manufacturers rely on the availability of basic scientific discoveries and diverse knowledge in order to sell products which have significant commercial value but are also standardized enough to be scalable in production because of capital costs. ICT content firms and service companies may be less dependent on breakthrough innovations and complex technologies, because competitiveness comes from incremental innovations in digital content. For example, introducing new software which is more user-friendly than previous versions is an important source of competitiveness for ICT content firms and does not require breakthrough innovations from universities. We hypothesize:

H2a: Proximity to the university and research culture will be positively associated with ICT product clustering.

$H 2 b$ : Proximity to the university and research culture will not be associated with ICT content clustering. 
Another important local consideration is the existence of local enterprise networks and demand. On one hand, low density of enterprises could restrict exploration activity in the ICT sector since a more closed system has limited networks, positioning one focal firm to draw on a relatively smaller pool of novel information (Ahuja, 2000). However, low density networks can also benefit from exploration effort and development of internal routines (Walter et. al. 2013) which reduce costs and streamline processes. In contrast, more open and higher density networks feature a variety of possibly conflicting norms and routines, as well as problem solving approaches. Ahuja (2000) described these contradictory effects of network openness and density on innovation and decision-making; high density networks do not guarantee that a firm will realize commercial potential of existing information and knowledge. In fact, firms which draw on available knowledge and networks may fail to capitalize on discoveries generated by networks - and there may be fewer potential start-ups arising to commercialize new ideas (Audretsch and Lehmann, 2005). Further, more open and denser enterprise networks are also known to be more unstable (Soda et. al. 2004) and this may raise uncertainty and thereby, reduce the stability and integration abilities needed to take new ideas from the discovery to the market. Research shows that more closed networks may generate more trust and reciprocity, and in this way, low density networks may enhance problem solving and attract technology companies with available solutions (Rowley et. al., 2000).

It could be, then, that high density networks induce a de-clustering effect because heterogeneity of firms within an area may have different culture, incentives and norms, making knowledge transfer and refinement among them difficult and expensive (Lane and Lubatkin, 1998; Rothaermel and Deeds, 2004). This could be especially meaningful for ICT clustering because more diversity in technology-oriented firms and networks may lead to misalignments in contracting and conmmercialization agreements thereby raising transaction costs (Lambert, 1998). For example, disagreements over intellectual property ownership and rights to licensing revenues could be more likely in high density, diverse networks where norms and cultural expectations differ. Thus, firms which need to make location decisions may need to account for network density. We hypothesise that higher network density will negatively affect both types of ICT firm clustering:

\section{H3a: Higher enterprise networks density negatively affects ICT product clustering.} H3b: Higher enterprise networks density negatively affects ICT content clustering.

Although the literature on networks and innovation highlights an innovation advantage of higher enterprise density and more openness (Borgatti, 2005), it explicitly assumes an equal distribution of information across a cluster. We argue that this is truly a hypothetical which is unlikely to hold in real-time in the ICT sector, given the nature and costs of exploration, R\&D activities and ownership of intellectual property. Firms in the ICT sector exploit information and discovery, so high density networks and openness can actually enable competitors within a cluster to observe a focal firm. Competitors and collaborators who become easily aware of a discovery may more easily attempt to copy, pre-empt, re-engineer or invent around such discoveries (Gilbert and Newbery, 1982; Ziedonis, 2004). Having university facilities and staff in proximity to clusters allows resources like university labs to serve as testing platforms for firms. This can have the effect of making knowledge flow more transparent and more difficult to hide, and increases the commercialization risks for new firms. The presence of other knowledge-sharing partners such 
as university-business partnerships and accelerators may further intensify information exchange and trigger information leakage.

ICT product firms have big concerns about intellectual property protections and may have to make large investments in the process of commercializing a physical product. This means ICT product firms may actually be hurt by high density networks, because they may be less able to protect and maintain secrecy related to their products. In this way, the university environment, by acting as a hub of ideas and human capital, as well as a testing facility, could moderate the relationship of network density and ICT product clustering. On the other hand, it is likely that ICT content firms are less sensitive, due to the nature of digital goods: ICT content firms do not rely on extensive and costly $\mathrm{R} \& \mathrm{D}$ and testing in order to exploit economies of scale. ICT content firms do not have the overhead costs that ICT product firms incur, and can be smaller in size. These firms operate in a dynamic environment characterized by lots of change and relatively low-cost incremental improvements in software. ICT content firms thus should basically be unaffected by the presence of a university given higher enterprise density. We hypothesize:

H4a: The relationship between ICT product clustering and higher enterprise network density is negatively moderated by presence of a university and research labs (knowledge leaking effect).

H4a: The relationship between ICT content clustering and higher enterprise network density is not affected by the presence of a university and research labs.

\section{Data and methods}

Our dataset is created by matching data from multiple sources. Our main source is Eurostat's European Urban Audit, for our dependent variable and control variables, and the Doing Business project, World Bank for our key explanatory variables. Additional variables come from the European Commission, World Economic Forum and World Bank. The Urban Audit data is collected every three years by Eurostat (2000-2004; 2004-2006; 2007-2009) with the key years 2004, 2006, 2009; the Doing Business data is available starting 2003. We thus take the equivalent year average of Doing Business data: 2004-2005; 2006-2007; 2008-2009. Our final dataset yields 227 cities across 22 European countries. We obtain our samples after accounting for data discrepancies, data availability for the dependent variable and removing outliers ${ }^{2}$.

The European Urban Audit (Eurostat, 2012) is a relatively new data source which provides standardized and disaggregated urban data which has been previously difficult to obtain, now enabling matching to the country level. Our approach to analyzing ICT clustering in this paper includes examining heterogeneity across regions (Saxenian, 1994; Brenner and Mühlig, 2013) as well as leveraging our data sources to for sophisticated data aggregation at different levels by geographical unit.

\footnotetext{
${ }^{2}$ Lichtenstein and Austria were dropped from both samples as only one city per country observation was available. The higher number of Eastern European cities in the ICT product sample could be explained by relocation effects (Manolova et al., 2008).
} 
Cities are broadly integrated economic areas and more suitable units for analysis than countries or regions (see Glaeser et al., 2010, 1995; Acs and Armington, 2004, 2002). Most research on business environment and regulation addresses countries (e.g., Acs et al., 2008; Manolova et al., 2008; Klapper et al., 2006) and most of research on clustering addresses regions (Brenner, 2001, 2004; Brenner and Mühlig, 2013), and a multi-level approach focused on the city has been neglected. Our local unit of analysis is the Functional Urban Area (formerly known as larger urban zone LUZ), which consists of a core city and its commuting zone. A core city is a local administrative unit (LAU) where the majority of the population lives in an urban centre of at least 50,000 inhabitants (Eurostat, 2015). The "core city" definition used in the Urban Audit corresponds to the "administrative city" with political responsibility (usually the municipality or equivalent) in all cases, with the exception of Brussels and Cyprus.

\section{Variables}

Our dependent variables reflect ICT clustering in two types of activity - ICT products and ICT content. We disaggregate into two types of ICT activities to capture heterogeneity of outcomes (Wiklund et al., 2011). As described in detail earlier in the paper, ICT product firms and ICT content firms are characterized by different goods and products, serve different types of markets and consumers, and as a result can vary in terms of their overhead requirements, intellectual property needs, information and human capital deployment and other costs. ICT product clustering is measured as the number of companies manufacturing ICT products of 1000 registered in a city, in logarithms; ICT content clustering is measured as the number of companies manufacturing ICT content of 1000 registered in a city, in logarithms. Both of our measures are taken from from Eurostat (2012). See Table 1 for variables, sources and descriptive statistics.

\section{Insert Table 1 here}

Our key explanatory variables at the country-level come from the World Bank's Doing Business database and the 2012-2013 Global Competitiveness Report. The country-level regulatory data from the Doing Business project reflects key dimensions of national business environment: Starting a business, registering property and enforcing contracts. For each dimension, we examine time costs (time needed to comply with requirements) and financial costs (cost of complying with requirements) because they represent two different regulatory tools available to policymakers. We use the following measures: Number of days required to start a business, cost as percent of national per capita income to start a business, number of days required to register property, cost as percent of property value to register property, number of days to get a contract enforce, cost of contract enforcement as percent of the claim value. The full range of combinations of policy dimensions and burdens is simply not possible to study, but our measures effectively reflect key regulations identified by the comparative cross-national literature (Klapper et al., 2006; Djankov et al., 2002). The justification for our approach is simple. Studies on business environment often select one or two measures or use indices (see Stenholm et al., 2013), limiting analytical depth. In addition, though poorer countries have more entry regulation than richer countries (Djankov et al., 2002), the type of entry burden could matter but is unexplored. 
Our main explanatory variables at the city-level come from the European Urban Audit (EUA) dataset (Eurostat, 2012). The EUA reflects key local content characteristics such as enterprise density, availability of human resources and a university, industry characteristics of a place, networks and existing infrastructure, level of entrepreneurial activity as well as other socioeconomic characteristics that affect clustering in cities (Saxenian, 1994; Druilhe and Garnsey, 2000; Bresnahan et al., 2001; Breznitz, 2007). We use a city type dummy for research center city to account for proximity to a university and research facilities. This classification is taken from XXX and reflects the availability of a university and research environment in a city. Research cities serve as centers of research and higher education, including science and technology-related corporate activities and can be well-connected with industry around the world (State of European Cities Report, 2007). Our variable for enterprise density network captures the intensity of networks within the city which may affect clustering (Glaeser et. al., 1995; Lane and Lubatkin, 1998; Rothaermel and Deeds, 2004; Cappelli et al., 2014). This is measured as the number of firms per 1000 residents in a city, and is taken from the Urban Audit.

We also control for several factors. We control for human capital given the importance of scale and size of economic activity (Armington and Acs, 2002; Saxenian, 1999) using a knowledge hub city dummy. We take this city classification from (State of European Cities Report, 2007) It identifies a city which can host science clusters (Cooke et al., 2005) and universities (Audretsch and Lehmann, 2005) which in turn, can positively affect knowledge diffusion and clustering (Audretsch and Feldman, 1996). Knowledge hub cities, such as London, may rise above national urban hierarchy to the forefront of international industry, business and financial services, and become well-connected globally and attract high levels of talent (State of European Cities Report, 2007). We control for the proportion of employment across sectors using $\mathrm{NACE}^{3}$ classification (Thurik et al., 2008) and new firm entry rate (Audretsch and Feldman, 1996; Audretsch and Lehnmann, 2005; Audretsch and Keilbach, 2007). To account for location, which is important because of delocalization of IT services in Eastern Europe, we include a dummy "East" which assigns a value of one if a city is located in Eastern Europe and 0 if in Western Europe (Aidis et. al., 2008). This also captures competitive and institutional phenomenon such as labor market trends, e.g., informality (Sobel 2008; Manolova et al., 2008). Along with countrylevel institutional controls we include University-industry collaboration in R\&D at a country level. This variable is normalised from 0 to 100 and illustrates to what extent do business and universities collaborate on research and development $(\mathrm{R} \& \mathrm{D})$ in a country; $0=$ do not collaborate at all; $100=$ collaborate extensively. This is the only variable taken from the World economic Forum The Global Competitiveness Report 2012-2013. Finally, we include year dummies as a time dimension.

\section{Empirical strategy}

We use a nested multi-level model to address interdependencies at different geographic levels. Since ICT clusters in our sample are assigned both to a city and a country, we impose a hierarchical structure such that ICT clusters are nested into their respective region, which in turn nest into the corresponding country. Following the multilevel literature (Besag et al. 1991;

\footnotetext{
${ }^{3}$ NACE stands for "Nomenclature Generale des Activites Economiques dans I Union Europeenne" and is the European standard for industry classification, introduced in 1970. The most recent version (2008) is based on International Standard Industrial Classification (ISIC) of the United Nations for economic activities. Of eight aggregated sectors, two (construction; ICT and other services) were dropped to avoid perfect multicollinearity.
} 
Langford et al. 1999), the effects of unobserved heterogeneity are estimated using the following nested two-level model:

$\operatorname{LnY}_{\mathrm{i}(\mathrm{cnt})=} \beta_{0}+\sum_{i=1}^{227} \beta_{i} x_{i(c n t)}+\rho_{i}+\rho_{c n t}+u_{i(c n t)}$

where $\mathrm{LnY}_{\mathrm{i}(\mathrm{cnt})}$ stands for the log of number of ICT content or ICT product firms per 1000 residents in a city $\mathrm{i}$, nested in a country $C N T$. Since the method allows the use of covariates at any level in the proposed hierarchy, the $r$ covariates contain the urban characteristics and the corresponding coefficient of each covariate. The random intercepts are measured at urban $\rho_{i}$ and national $\rho_{c n t} \square$ levels and captures unobserved heterogeneity at those levels. The random intercepts are assumed independent (given the covariates) and normally distributed with zero mean and constant variance. Following Langford et al. (1999), the error terms are assumed to be independent and can therefore be directly estimated.

By using a multilevel model, the influence of each level can be controlled for and measured, which is particularly useful if dealing with possible endogeneity bias (Skrondal and RabeHesketh 2004) and potential spatial autocorrelation (Bhat 2000; Mundlak, 1988). ICT clustering might for example be more correlated within a given region or country than across regions (countries). Introducing varying intercepts induces dependence among cities as well as ICT clusters, and can be interpreted as unobserved heterogeneity at the different levels.

We calculate variance inflation factors (VIF) for our variables. Apart from starting a business procedures and enforcing contracts procedures, we found no indication of multicollinearity. VIF for all other variables are well below the conventional level of 10 . We conservatively use simple correlations to guide our approach to multicollinearity, using a cut-off of 0.7 .

\section{Robustness check}

Before introducing explanatory variables, we consider the hierarchical structure of the data by estimating variances for the random intercepts at the two levels, excluding the regressors. This provides information about how the proposed hierarchical structure relates to ICT clustering and how much of the variance that can be attributed to the two geographical levels. Hence, the following unconditional model is estimated in a first step:

$\operatorname{LnY} Y_{\mathrm{i}(\mathrm{cnt})=} \beta_{0}+\rho_{i}+\rho_{c n t}+e_{i(\mathrm{cn} t)}$

where $\mathrm{LnY}_{\mathrm{i}(\mathrm{cnt})}$ is the $\log$ of number of ICT content or ICT product firms per 1000 residents in a city $i$ and country cnt and $\beta_{0}$ is an intercept. The results of estimating the unconditional model in Equation 2 show that the sample of 227 clusters is nested into 227 cities and 22 countries. The average number of ICT clusters available over time for each city is 1.75 and 17.1 for each country. The between-level heterogeneity at the city and national level is significant and positive, implying significant variance across and within the imposed hierarchy. This can also be described by the intra-class correlation coefficient (ICC). The ICC measures the degree of correlation among observations within a city and a country is a useful tool to evaluate how much of total variance in ICT clustering can be assigned to these two different geographical levels. The 
ICC coefficient ranges from 0 to 1 , where a value of 0 indicates that the grouping bears no information and 1 indicate that all units in the group are identical.

\section{Multi-level nested model verification}

The estimated ICC coefficients for the unconditional model are presented in Table 2 and indicate the direct effect of how these two geographical levels influence ICT product and ICT content clustering. Results for ICT product clustering show that the ICC is 0.34 for country and 0.54 for city. A relatively lower variance at the country level indicates a smaller part of the variance in ICT product clustering is explained by characteristics of the country (34\%) and most variance is explained by city characteristics (54\%). This indicate that the main factors explaining ICT product clustering are local city attributes, compared to the aggregated country level which accounts for only $34 \%$ of the explained variance. Results for ICT content show that the ICC is 0.96 for city and 0.83 for country. This indicates that a large part of the variance is explained by characteristics of country $(83 \%)$ but also most of the variance is explained by city variation (96\%). This indicates that the main factors explaining ICT content clustering are both city and country level attributes, in relation to the more disaggregated city level ( $91 \%$ of the variance).

\section{Insert Table 2 about here}

Local ecosytems and urban socioeconomic environment are statistically significant for both ICT product and ICT content clustering, while country variance has a stronger impact on ICT content clustering: $83 \%$ variance in ICT content clustering vs. $34 \%$ in the ICT product clustering. This supports $\mathrm{H} 1$ on the role of national level institutions being more relevant for ICT content clustering and to a lesser extent to the ICT product clustering. This is shown in Table 2 and adds economic significance to the analysis that follows.

\section{Results}

Table 3 presents the results from running the regression model in equation 1, including the regressors. Unmeasured heterogeneity is controlled for by allowing the results to vary by level. The model is estimated using the full sample and thereafter addresses the influence of urban and country institutions. We find that most variance in ICT product clustering is explained by city characteristics (54\%), but we also find that national institutions play an important role (34\%).

We find that not all types of national regulatory conditions matter, and the ones that matter are important in different ways. Further, we find that ICT content clustering is more affected than the ICT product clustering. This could be interpreted as requiring a better match with national regulation, culture, language and technical requirements, marketing strategies and understanding customer characteristics in a given country. Overall, we find support for H1. Starting a business. We find that more time required to start a business discourages ICT product clustering. We find that higher financial costs to start a business have initial positive affect on ICT product clustering, which reflects the level of financial commitment and quality of business (Djankov et. al., 2002). However a higher increase in the financial burden is negatively associated with ICT 
product clustering and the relationship flips (inverted U-shape). Neither the time nor the financial costs to start a business seem to matter for ICT content firms. This could be because many ICT content firms may operate largely online and have the freedom to register in countries which are less costly from a regulatory perspective. This is especially salient in Europe, where firms can move fairly easily between countries if they are not capital-intensive. Registering property. We find that neither the time costs or the financial costs to register property matter for ICT product firms. We find that the time to register property has a significant nonlinear impact on ICT content clustering, demonstrating an inverted U-shape where the relationship is initially positive which reflects the level of financial commitment and quality of business, then becomes negative should the admin burden be very high. Interestingly, financial costs of registering property do not matter for ICT content firms. Enforcing contracts. We find that more time to enforce contracts encourages ICT product clustering, but more expensive contract enforcement does not matter for ICT product firms. Time period associated with contract enforcement is negatively associated with ICT content clustering omplies the formula "the longer contract enforcement - the less clustering". The financial cost of enforcing contracts does not affect ICT content clustering. In brief, administrative burden rather than financial burden has a greater negative effect on the ICT clustering. The effect is higher for ICT content clustering, than ICT product clustering.

We now turn to the city level. We find that ICT product clustering is positively affected by research city or university presence, supporting $\mathrm{H} 2 \mathrm{a}$ and similar findings in other studies (Audretsch and Keilbach, 2007; Audretsch and Feldman, 1996). This could mean ICT product firms are employing new and hybrid knowledge, and may be accessing scientific facilities as they engage in engineering processes, product development and creation. We find that ICT content is not affected by research city or university presence, discarding $\mathrm{H} 2 \mathrm{~b}$.

When it comes to network density, we find that ICT product clustering is associated with lower enterprise density and closeness of networks, supporting H3a. This is consistent with previous research which argues in favour of the effect of proximity to firms with similar knowledge as opposed to diversity per se (Frenken et al., 2007; Boschma and Frenken, 2011). H3b is also supported: We find that ICT content clustering is negatively associated with enterprise density and closeness of networks. Network closeness and enterprise density also known as business saturation is negatively affected to both types of ICT clustering with the presence of a university in a highly saturated environment be a potential threat to the ICT product firms.

We now turn to the moderating effect of universities. H4a posited a leakage effect on ICT product clustering: Although the effect is in fact statistically significant at $15 \%$ level and the coefficient is negative, this is not robust enough to reject the null of existence of the effect. Therefore we do not find support for $\mathrm{H} 4 \mathrm{a}$ and we cannot conclude that university presence in a dense network harms ICT product firms. The presence of a university does not moderate the relationship between intensity of ICT content clustering and enterprise density, supporting H4b.

Several of the control variables are interesting. We find location in Eastern Europe is associated with greater ICT product clustering than content clustering. The difference in means effect is statistically significant for the Eastern European cities only. This could be explained by weaker institutions or cheaper labor and access to networks and universities (Aidis et. al., 2008; 
Manolova et. al., 2008; Estrin et. al., 2013). Interestingly, we do not find that status as a knowledge city matters for either type of ICT clustering activities. However, we do find that industry diversity in a city matters. In particular, employment in finance, trade and ICT content manufacturing, positively affect ICT content clustering while relatively higher employment in construction and manufacturing sector deter ICT content clustering. With respect to ICT product clustering, similar patterns hold with employment in trade positively affecting ICT product clustering and construction deterring the ICT product clustering. University-industry collaboration in $\mathrm{R} \& \mathrm{D}$ in each specific country is not found to affect ICT product clustering, but has significant negative affect on ICT content clustering. Although we do not hypothesize on the direction of this relationship it would expected to be positive as firms benefit from on average higher knowledge diffusion and cooperation between universities and industry. The negative effect maybe the result of innovation openness and negative externalities related to knowledge leakage and appropriation of knowledge by the ICT companies (Ziedonis, 2004; Cappellli et. al., 2014)

\section{Conclusion}

Our findings indicate that the national and urban context surrounding ICT clustering should be treated as highly nuanced. At the country level, we find that different regulatory dimensions and the type of cost imposed by policy both matter. At the city level, we find that proximity to university presence and related knowledge resources is important for ICT product firms but not ICT content firms, and that enterprise network density harms both types of ICT clustering. We find that co-location of university and dense enterprise networks do not affect ICT clustering.

We make two important contributions in this paper. First, we address country and city characteristics which influence ICT product and ICT content clustering. This helps us better narrow the how digital product is affected jointly by multiple levels of factors (Rodríguez-Pose 2001). Our findings at both levels of geography help to "unpack" the local context characteristics that drive clusters (Porter, 1990; Saxenian, 1994, 1999; Brenner and Mühlig, 2013) and country business environment and are both relevant for urban policymakers interested in supporting ICT clustering and knowledge spillovers (Audretsch, 2007). In particular, we focus on the role of country regulatory factors as well as city factors related to university presence and network density. Second, we make a methodological contribution by using a nested multi-level model which accounts for hierarchical structure, in which countries represents the "higher" level and cities represent the "lower" level, while both vary within a time dimension. This allows us to control for clustering of the data first within country, and second, within city (Estrin et al., 2013; Rabe-Hesketh et al., 2005).

Our multi-level approach highlights the need for researchers to consider heterogeneity in the drivers and the nature of digital products (see LEAD, 2014). A blanket approach is not realistic in the policy environment - in fact, some regulatory arrangements simply matter less and some matter more, depending on if firms are producing ICT products or ICT content. 
Future research may focus on potential new ICT product or new ICT content firms and assessing the sensitivity of entrepreneurs to market conditions at various geographical dimensions (locally, regionally, nationally). Questions could include, for example, when and how to absorb risk and choose the best entry strategy. Scholars could consider a threshold in anticipating administrative burden with complicated legal arrangements, e.g, how they might design legal arrangements given the idiosyncrasy in the effect of various financial and administrative burdens on ICT clustering. Local policy makers could extend and expand our multi-level approach by adding business characteristics at the city level and control for a variety of local context characteristics such as infrastructure, legal environment, networks, market size (Acs et . al., 2014; Sczerb et. al., 2013). Managerial considerations could link this multilevel nested model approach to further design business models for ICT content and ICT product manufacturers, taking into account effects of local context and regulation. For example, managers of ICT content firms may want to negotiate with national and European policy makers about regulation. Managers of ICT product may want to focus less on national standards, legislation and culture, but rather tap into local knowledge, collaboration with universities and research labs, addressing the industrial diversity of local business that may be complementary. Another question concerns other types of national and urban policies. Scholars and policy makers may apply our approach to modelling ICT clustering to cluster formation in other sectors, an in particular with high-technology heterogeneous products and draw conclusions.

\section{REFERENCES}

Armington, C., Acs, Z. J. (2002). The determinants of regional variation in new firm formation. Regional studies, 36(1), 33-45.

Acs, Z. J., Desai, S., Klapper, L. F. (2008). What does "entrepreneurship" data really show?. Small Business Economics, 31(3), 265-281.

Ács, Z. J., Autio, E., \& Szerb, L. (2014). National systems of entrepreneurship: Measurement issues and policy implications. Research Policy, 43(3), 476-494.

Ahuja, G. (2000). Collaboration networks, structural holes, and innovation: A longitudinal study. Administrative science quarterly, 45(3), 425-455.

Aidis, R., Estrin, S. and Mickiewicz, T. (2008) "Institutions and Entrepreneurship Development in Russia: A Comparative Perspective," Journal of Business Venturing, 23: 656-672.

Audretsch, D., Feldman, M. (1996). RandD Spillovers and the Geography of Innovation and Production. American Economic Review, 86, 630-640.

Audretsch, D., Lehmann, E. (2005). Does the knowledge spillover theory of entrepreneurship hold for regions? Research Policy, 34, 1191-1202.

Audretsch, D., Keilbach, M. (2007). The Theory of Knowledge Spillover Entrepreneurship. Journal of Management Studies, 44, 1242-1254.

Beckman, C., Eisenhardt, K., Kotha, S., Meyer, A., Rajagopalan, N. (2012). Technology entrepreneurship. Strategic Entrepreneurship Journal, 6(2), 89-93.

Bell, M., Pavitt, K. (1993). Technological Accumulation and Industrial Growth: Contrasts Between Developed and Developing Countries. Industrial and Corporate Change, 2, 157-209.

Besag, J., York, J., Mollie, A. (1991). Bayesian image restoration, with two applications in spatial statistics. Ann. Inst. Statist. Math., 43, 1-75. 
Bhat, C. R. (2000). A multi-level cross-classified model for discrete response variables.

Transportation Research Part B: Methodological, 34(7), 567-582.

Bilbao-Osorio, B., Rodríguez-Pose, A. (2004). From R\&D to innovation and economic growth in the EU. Growth and Change, 35(4), 434-455.

Blazek, J., Zizalova, P., Rumpel, P., Skokan, K. and Chladek, P. (2012) "Emerging regional innovation strategies in Central Europe: institutions and regional leadership in generating strategic outcomes," European Urban and Regional Studies, 20 (2): 275-294. Borgatti, S. P. (2005). Centrality and network flow. Social networks, 27(1), 55-71.

Boschma, R., Frenken, K. (2011). The emerging empirics of evolutionary economic geography. Journal of Economic Geography, 11(2), 295-307

Brenner, T. (2001). Simulating the evolution of localised industrial clusters-an identification of the basic mechanisms. Journal of Artificial Societies and Social Simulation, 4(3), 4.

Brenner, T. (2004). Local industrial clusters: existence, emergence and evolution. Routledge.

Brenner, T., Mühlig, A. (2013). Factors and mechanisms causing the emergence of local industrial clusters: a summary of 159 cases. Regional Studies, 47(4), 480-507.

Bresnahan, T., Gambardella, A., Saxenian, A. (2001). Old economy' inputs for 'new economy'outcomes: cluster formation in the new Silicon Valleys. Industrial and corporate change, 10(4), 835-860.

Breznitz, D. (2007). Industrial R\&D as a national policy: Horizontal technology policies and industry-state co-evolution in the growth of the Israeli software industry. Research Policy, 36(9), 1465-1482.

Bruton, G., Ahlstrom, D., Li, H. (2010). Institutional theory and entrepreneurship: Where are We Now and Where do We Need to Move in the Future. Entrepreneurship Theory and Practice, 421440.

Cappelli, R., Czarnitzki, D., Kraft, K. (2014). Sources of spillovers for imitation and innovation. Research Policy, 43, 115-120.

Chavis, L., Klapper, L., Love, I. (2011). The Impact of the Business Environment on Young Firm Financing. World Bank Economic Review, 25, 486-507.

Desai, S., Acs, Z. J., \& Weitzel, U. (2013). A Model of Destructive Entrepreneurship Insight for Conflict and Postconflict Recovery. Journal of Conflict Resolution, 57(1), 20-40.

Djankov, S., La Porta, R., Lopez-de-Silanes, F., Shleifer, A. (2002). The Regulation of Entry. Quarterly Journal of Economics, 117: 1-37.

Druilhe, C., Garnsey, E. (2000). Emergence and growth of high-tech activity in Cambridge and Grenoble. Entrepreneurship \& Regional Development, 12(2), 163-177.

Gilbert, R. J., Newbery, D. M. (1982). Preemptive patenting and the persistence of monopoly. The American Economic Review, 514-526.

Estrin, S., Korosteleva, J., Mickiewicz, T. (2013). Which institutions encourage entrepreneurial growth aspirations? Journal of Business Venturing, 28, 564-580.

The State of European cities report (2007)

http://www.eukn.org/France/fr_en/E_library/Urban_Policy Accessed 7 March 2015

European Commission, (2011). Business Dynamics: Start-ups, Business Transfers and

Bankruptcy: The economic impact of legal and administrative procedures for licensing, business transfers and bankruptcy on entrepreneurship in Europe. Accessed June 21, 2013.

European Commission (2012). ICT Technologies Work Programme 2013

http://cordis.europa.eu/fp7/ict/docs/ict-wp2013-10-7-2013.pdf, date last accessed June 21, 2013. Accessed 15 July 2014. 
Eurostat (2012) City statistics Urban audit.

http://epp.eurostat.ec.europa.eu/portal/page/portal/region_cities/city_urban. Accessed 7 April 2013.

Eurostat (2015). What is a city? - Spatial units. http://ec.europa.eu/eurostat/web/cities/spatialunits. Accessed 7 March 2015.

Frenken, K., Van Oort, F., Verburg, T. (2007). Related variety, unrelated variety and regional economic growth. Regional studies, 41(5), 685-697

Garud, R., Karnøe, P. (2003). Bricolage versus Breakthrough: Distributed and Embedded Agency in Technology Entrepreneurship. Research Policy, 32, 277-300.

Glaeser, E., Scheinkman, J., Shleifer, A. (1995). Economic Growth in a Cross-section of Cities. Journal of Monetary Economics, 36, 117-143.

Glaeser, E., Rosenthal, S., Strange, W. (2010). Urban Economics and Entrepreneurship. Journal of Urban Economics, 67, 1-14.

Hoang, H. A., Rothaermel, F. T. (2010). Leveraging internal and external experience: exploration, exploitation, and R\&D project performance. Strategic Management Journal, 31(7), 734-758

Holmen, M., McKelvey, M. (2005). Systematic evolutionary studies of regional restructuration it and biotech case-studies in Sweden. European Urban and Regional Studies, 12(3), 209-228.

Iammarino, S., Jona-Lasinio, C. (2013). ICT production and labour productivity in the Italian regions. European Urban and Regional Studies, doi: 0969776412464504 Innovation Observatory (2013) Selling ICT Products and Services to Business: Better Market Segmentation Report. http://www.innovationobservatory.com/reports/latesttitles Accessed June 21,2013.

Jorgenson, D., Stiroh, K., Gordon, R., Sichel, D. (2000). Raising the Speed Limit: US Economic Growth in the Information Age. Brookings Papers on Economic Activity, 1, 125-235.

Kan, M. (2014) WhatsApp deal gives Facebook a path to crowded China market. http://www.pcworld.com/article/2099580. Accessed 7 march 2015.

Krugman, P. R. (1991). Geography and trade. MIT press.

Klapper, L., Laeven, L., Rajan, R. (2006). Entry Regulation as Barrier to Entrepreneurship. Journal of Financial Economics, 82, 591-629.

Lambert, D. M., Cooper, M. C., Pagh, J. D. (1998). Supply chain management: implementation issues and research opportunities. The international journal of logistics Management, 9(2), 1-20. Langford, I. H., Leyland, A. H., Rasbash, J., Goldstein, H. (1999). Multilevel modelling of the geographical distributions of diseases. Journal of the Royal Statistical Society: Series C (Applied Statistics), 48(2), 253-268.

Lane, P. J. Lubatkin, M. (1998). Relative absorptive capacity and interorganizational learning. Strategic management journal, 19(5), 461-477.

LEAD (2014). e-Leadership Skills for Competitiveness and Innovation. European Commission, Directorate-General for Enterprise and Industry. http://ec.europa.eu/enterprise/sectors/ict/files/eskills/insead_eleadership_en.pdf. Accessed 15 July 2014.

Leitao, J., Baptista, R. (2008). Inward FDI and ICT: Are they a joint technological driver of entrepreneurship? In Engineering Management Conference. IEMC Europe 2008. (pp. 1-5). IEEE. 
Leitao, J., Baptista, R. (2011). Inward FDI and ICT: are they a joint technological driver of entrepreneurship? International Journal of Technology Transfer and Commercialisation, 10(3), 268-288.

Manolova, T., Eunni, R., Gyoshev, B. (2008). Institutional Environments for Entrepreneurship: Evidence from Emerging Economies in Eastern Europe. Entrepreneurship: Theory and Practice, 32, 203-218.

McCann, P., Ortega-Argilés, R. (2013). Smart specialization, regional growth and applications to European union cohesion policy. Regional Studies, 1-12.

Mullan, E. (2011). What is Digital Content? EContent Magazine. http://www.econtentmag.com/Articles/Resources/Defining-EContent/What-is-Digital-Content-

79501.htm Accessed 7 March 2015

Mundlak, Y. (1988). Endogenous technology and the measurement of productivity (pp. 316331).

IFPRI.

Payne, G., Moore, C., Griffis, S., Autry, C. (2011). Multievel challenges and opportunities in social capital research. Journal of Management, 37, 491-520. Phan, P., Foo, M. (2004). Technological Entrepreneurship in Emerging Regions. Journal of Business Venturing, $\quad 19, \quad 1-5$. PORTER M. E. (1990) Competitive Advantage of Nations. Macmillan, London.

Porter, M. E. (1998). Clusters and the new economics of competition, Harvard Business Review, 76(6), 77-90.

Rabe-Hesketh, S., Skrondal, A., Pickles, A. (2005). Maximum likelihood estimation of limited and discrete dependent variable models with nested random. Journal of Econometrics, 128: 301323.

Rodrigues-Pose (2001). Is R\&D investment in lagging areas of Europe worthwhile? Theory and Empirical evidence. Papers in Regional Sciences 80, 275-295.

Rothaermel, F. T., Deeds, D. L. (2004). Exploration and exploitation alliances in biotechnology: a system of new product development. Strategic management journal, 25(3), 201-221.

Saxenian, A. (1994). Regional networks: industrial adaptation in Silicon Valley and route 128

Saxenian, A. (1999). Silicon Valley's New Immigrant Entrepreneurs, Public Policy Institute of

California, San Francisco.

Siegel, D. (Ed) (2006) Technological Entrepreneurship, Northampton, MA: Edward Elgar.

Shan, W., Walker, G., Kogut, B. (1994). Interfirm cooperation and startup innovation in the biotechnology industry. Strategic management journal, 15(5), 387-394

Soda, G., Usai, A., Zaheer, A. (2004). Network memory: The influence of past and current networks on performance. Academy of Management Journal,47(6), 893-906.

Sobel, R. (2008). Testing Baumol: Institutional Quality and the Productivity of Entrepreneurship. Journal of Business Venturing, 23, 641-655.

Skrondal, A., Rabe-Hesketh, S. (2004). Generalized latent variable modeling: Multilevel, longitudinal, and structural equation models. CRC Press.

Stenholm, P., Acs, Z., Wuebker, R. (2013). Exploring Country-level Institutional Arrangements on Rate and Type of Entrepreneurial Activity. Journal of Business Venturing, 28: 176-193.

Szerb, L., Acs, Z., Autio, E., Ortega-Argiles, R., Komlosi, E. et. al. 2013. REDI: The Regional Entrepreneurship and Development Index - Measuring regional entrepreneurship. Final Report. European Commission, Directorate-General for Regional and Urban policy. REGIO DG 02 Communication. 
Thurik, R., Carree, M., van Stel, A., Audretsch, D. (2008). Does Self-Employment Reduce Unemployment? Journal of Business Venturing, 23, 673-686.

Van der Linde, C. (2003). The demography of clusters-findings from the cluster meta-study. In Innovation clusters and interregional competition (pp. 130-149). Springer Berlin Heidelberg. Villasenor, J. (2013). Six 'Megatrends' That Will Shape The Future Of Digital Media. Forbes Magazine. http://www.brookings.edu/research/opinions/2013/05/01-megatrends-future-digitalmedia-villasenor Accessed 7 March 2015

$\mathrm{Vu}, \mathrm{K}$. (2011). ICT as a Source of Economic Growth in the Information Age: Empirical Evidence from the 1996-2005 Period. Telecommunications Policy, 35, 357-372.

Walter, J., Lechner. C., Kellermanns, FW. (2013). Learning activities, exploration, and the performance of strategic initiatives. Journal of Management. doi: 0149206313506463.

Wiklund, J. Davidsson, P., Audretsch, D., Karlsson, C. (2011). The Future of Entrepreneurship Research. Entrepreneurship Theory and Practice, 35, 1-9.

Woolley, J. L., \& Rottner, R. M. (2008). Innovation policy and nanotechnology entrepreneurship. Entrepreneurship theory and practice, 32(5), 791-811.

Woolley, J. L. (2014). The creation and configuration of infrastructure for entrepreneurship in emerging domains of activity. Entrepreneurship Theory and Practice, 38(4), 721-747.

World Bank (2012). Doing Business Report. www.doingbusiness.org Accessed March 19, 2013. Zahra, S. A., Wright, M. (2011). Entrepreneurship's next act. The Academy of Management Perspectives, 25(4), 67-83.

Ziedonis, R. H. (2004). Don't fence me in: Fragmented markets for technology and the patent acquisition strategies of firms. Management Science, 50(6), 804-820. 
Table 1: Variables, sources and summary statistics

\begin{tabular}{|c|c|c|c|c|c|c|}
\hline Variable & Description & Level & Mean & St.dev & Min & Max \\
\hline ICT content & $\begin{array}{c}\log \text { of (1+Firms producing ICT content per } 1000 \\
\text { firms registered })\end{array}$ & urban & 4.06 & 0.97 & 1.06 & 6.56 \\
\hline ICT product & $\begin{array}{c}\text { Log of (1+Firms manufacturing ICT products per } \\
1000 \text { firms registered })\end{array}$ & urban & 1.47 & 0.77 & 0.00 & 5.60 \\
\hline Knowledge city & $\begin{array}{l}\text { Key players in the global economy, positioned } \\
\text { above the national urban hierarchy, well- } \\
\text { connected to the world }\end{array}$ & urban & 0.27 & 0.44 & 0.00 & 1.00 \\
\hline Research city & $\begin{array}{l}\text { Centres of research and higher education, science } \\
\text { and technology related corporate activities; well- } \\
\text { connected internationally }\end{array}$ & urban & 0.07 & 0.26 & 0.00 & 1.00 \\
\hline East & $\begin{array}{c}\text { Dummy variable }=1 \text { if city is in the Eastern } \\
\text { Europe, zero otherwise }\end{array}$ & urban & 0.16 & 0.37 & 0.00 & 1.00 \\
\hline Enterprise intensity & $\begin{array}{l}\text { Number of firms per } 1000 \text { residents in a city also } \\
\text { known as business saturation index }\end{array}$ & urban & 0.06 & 0.03 & 0.00 & 0.20 \\
\hline Manufacturing & $\begin{array}{c}\text { Proportion of employment in energy, mining and } \\
\text { manufacturing }\end{array}$ & urban & 21.74 & 8.23 & 5.60 & 62.30 \\
\hline Finance & $\begin{array}{l}\text { Proportion employed in financial intermediation } \\
\text { and business services }\end{array}$ & urban & 19.16 & 7.31 & 3.30 & 53.50 \\
\hline Trade & Proportion employed in trade, restaurants, hotels & urban & 20.11 & 4.68 & 11.00 & 32.90 \\
\hline Transport & $\begin{array}{c}\text { Proportion employed in transport and } \\
\text { infrastructure }\end{array}$ & urban & 7.91 & 3.15 & 2.50 & 19.40 \\
\hline Construction & Proportion employed in construction & urban & 6.50 & 2.90 & 1.40 & 17.80 \\
\hline $\begin{array}{l}\text { Digital content } \\
\text { employment }\end{array}$ & $\begin{array}{c}\text { Proportion employed producing ICT content, } \\
\text { standardized }\end{array}$ & urban & 0.14 & 1.21 & -0.63 & 12.28 \\
\hline $\begin{array}{l}\text { Digital products } \\
\text { employment }\end{array}$ & $\begin{array}{c}\text { Proportion employed producing ICT products, } \\
\text { standardized }\end{array}$ & urban & 0.10 & 0.92 & -1.37 & 5.71 \\
\hline Business start-ups & $\begin{array}{l}\text { New firm formation as percentage to existing } \\
\text { firms }\end{array}$ & urban & 14.47 & 10.71 & 2.00 & 56.90 \\
\hline $\begin{array}{l}\text { Time- starting a } \\
\text { business }\end{array}$ & $\begin{array}{l}\text { The number of days required to start a business, } \\
\text { in a given country-year }\end{array}$ & country & 8.10 & 7.59 & 0.00 & 40.40 \\
\hline $\begin{array}{l}\text { Cost- starting a } \\
\text { business }\end{array}$ & $\begin{array}{l}\text { The cost to start a business, as \% of income per } \\
\text { capita, in a given country-year }\end{array}$ & country & 25.30 & 20.93 & 4.00 & 114.00 \\
\hline $\begin{array}{c}\text { Time }- \text { registering } \\
\text { property }\end{array}$ & $\begin{array}{l}\text { The number of days requires to register property, } \\
\text { in a given country-year }\end{array}$ & country & 4.68 & 2.79 & 0.50 & 12.77 \\
\hline $\begin{array}{l}\text { Cost- registering } \\
\text { property }\end{array}$ & $\begin{array}{l}\text { The cost of registering property as \% of property } \\
\text { value, in a given country-year }\end{array}$ & country & 61.86 & 71.49 & 1.00 & 391.00 \\
\hline $\begin{array}{l}\text { Time }- \text { enforcing } \\
\text { contracts }\end{array}$ & $\begin{array}{l}\text { The number of days to enforce contracts in a } \\
\text { given country-year }\end{array}$ & country & 20.77 & 6.42 & 8.80 & 33.50 \\
\hline $\begin{array}{l}\text { Cost- enforcing } \\
\text { contracts }\end{array}$ & $\begin{array}{l}\text { The cost of enforcing a contract as \% of the } \\
\text { claim, in a given country-year }\end{array}$ & country & 579.21 & 351.95 & 210.00 & 1440.0 \\
\hline University-industry & $\begin{array}{c}\text { University-industry collaboration in R\&D0-100 } \\
\text { normalised }\end{array}$ & country & 33.37 & 28.23 & 3.00 & 95.00 \\
\hline
\end{tabular}

Source: Urban level: European Urban Audit, Eurostat (2014); National / country level: Doing Business Statistics World Bank (2012). University-industry cooperation in R\&D at a country level is taken from The Global Competitiveness Report 2012-2013 available at http://reports.weforum.org/global-competitiveness-report-2012-2013/ accessed: March 07, 2015. 
Table 2a: Interclass correlations for ICT content clustering

\begin{tabular}{|c|c|c|c|}
\hline Level & $I C C$ & St.err. & $95 \%$ conf. interval \\
\hline Country & 0.83 & 0.05 & $0.70 \quad 0.91$ \\
\hline City / country & 0.96 & 0.01 & $0.93 \quad 0.98$ \\
\hline
\end{tabular}

Table 2b: Interclass correlations for ICT product clustering

\begin{tabular}{|l|l|l|lc|}
\hline Level & ICC & St.err. & \multicolumn{2}{|l|}{ 95\% conf. interval } \\
\hline Country & 0.34 & 0.12 & 0.14 & 0.61 \\
\hline City / country & 0.54 & 0.10 & 0.34 & 0.72 \\
\hline
\end{tabular}


Table 3. Results from mixed-effects ML regressions, base sample and full sample=377 obs.

\begin{tabular}{|c|c|c|c|c|}
\hline \multirow{3}{*}{ Parameter } & \multicolumn{2}{|c|}{ ICT content } & \multicolumn{2}{|c|}{ ICT product } \\
\hline & Base model & Full & Base model & Full \\
\hline & (1) & (2) & (3) & (4) \\
\hline \multicolumn{5}{|c|}{ City level predictors } \\
\hline Research city $(\mathrm{H} 2)$ & & $0.09(0.12)$ & & $0.62 * * *(0.23)$ \\
\hline Enterprise intensity $(\mathrm{H3})$ & & $-5.89 * * *(1.08)$ & & $-6.11 * * *(1.89)$ \\
\hline Research city $x$ Enterprise intensity $(H 4)$ & & $1.62(2.15)$ & & $-5.80^{1}(4.01)$ \\
\hline Knowledge city & & $-0.01(0.03)$ & & $-0.03(0.07)$ \\
\hline East Europe city & & $-0.02(0.45)$ & & $0.34 *(0.19)$ \\
\hline Manufacturing & & $-0.005 *(0.003)$ & & $0.01(0.01)$ \\
\hline Finance & & $0.02 * * *(0.00)$ & & $0.001(0.000)$ \\
\hline Trade & & $0.01 * *(0.00)$ & & $0.02 * *(0.01)$ \\
\hline Transport & & $0.01(0.01)$ & & $0.01(0.01)$ \\
\hline Construction & & $-0.03 * * *(0.00)$ & & $-0.05 * *(0.01)$ \\
\hline Digital content employment & & $0.27 * * *(0.00)$ & & $0.14 * *(0.04)$ \\
\hline Digital products employment & & $-0.03^{* *}(0.00)$ & & $0.14 * * *(0.02)$ \\
\hline Business start-ups & & $0.01(0.01)$ & & $0.01 *(0.00)$ \\
\hline \multicolumn{5}{|c|}{ Country level predictors $(\mathrm{HI})$} \\
\hline $\begin{array}{l}\text { Time starting a business } \\
\text { Time starting a business sqrd }\end{array}$ & & $\begin{array}{l}0.01(0.01) \\
0.00(0.00)\end{array}$ & & $\begin{array}{l}-0.02 * * *(0.00) \\
0.00(0.00)\end{array}$ \\
\hline $\begin{array}{c}\text { Cost starting a business } \\
\text { Cost starting a business sqrd }\end{array}$ & & $\begin{array}{l}-0.12(0.10) \\
0.00(0.00)\end{array}$ & & $\begin{array}{l}0.15 * * *(0.03) \\
-0.01 * *(0.00)\end{array}$ \\
\hline $\begin{array}{l}\text { Time registering property } \\
\text { Time registering property sqrd }\end{array}$ & & $\begin{array}{l}0.01 * * *(0.00) \\
-0.01 * *(0.00)\end{array}$ & & $\begin{array}{l}0.00(0.00) \\
0.001(0.00)\end{array}$ \\
\hline $\begin{array}{l}\text { Cost registering property } \\
\text { Cost registering property sqrd }\end{array}$ & & $\begin{array}{l}0.09(0.19) \\
0.01(0.01)\end{array}$ & & $\begin{array}{l}-0.01(0.00) \\
0.00(0.00)\end{array}$ \\
\hline $\begin{array}{l}\text { Time enforcing contracts } \\
\text { Time enforcing contracts sqr }\end{array}$ & & $\begin{array}{l}-0.01 * * *(0.00) \\
0.001 * * *(0.00)\end{array}$ & & $\begin{array}{l}0.02 *(0.01) \\
0.00(0.00)\end{array}$ \\
\hline $\begin{array}{l}\text { Cost enforcing contracts } \\
\text { Cost enforcing contracts sqrd }\end{array}$ & & $\begin{array}{l}0.01(0.01) \\
-0.01 * *(0.00)\end{array}$ & & $\begin{array}{l}-0.01(0.00) \\
0.00(0.00)\end{array}$ \\
\hline University-industrycooperation & & $-0.01 * *(0.00)$ & & $0.01(0.01)$ \\
\hline Country dummy & NO & YES & NO & YES \\
\hline Year dummy & YES & YES & YES & YES \\
\hline Constant & $3.32 * * *(0.21)$ & $5.18 * * *(0.85)$ & $1.07 * * *(0.12)$ & $-0.69(0.41)$ \\
\hline Variance country (const) & $0.65 * * *(0.24)$ & $0.01 * *(0.00)$ & $0.15 * *(0.08)$ & $0.02 *(0.01)$ \\
\hline Variance city (const) & $0.10 * * *(0.01)$ & $0.03 * * *(0.00)$ & $0.08^{* * *}(0.02)$ & $0.06^{* * *}(0.02)$ \\
\hline LR test vs. linear, chi2 & 657.6 & 520.09 & 166.5 & 66.65 \\
\hline $\mathrm{AIC} / \mathrm{BIC}$ & $359 / 390$ & $127 / 257$ & $687 / 718$ & $610 / 740$ \\
\hline ICC country & 0.83 & 0.38 & 0.34 & 0.08 \\
\hline
\end{tabular}




\begin{tabular}{|c|l|l|l|l|}
\hline ICC city (country) & 0.96 & 0.59 & 0.54 & 0.34 \\
\hline Wald chi sq. & 26.38 & 1536.05 & 11.73 & 314.66 \\
\hline
\end{tabular}

Note: ${ }^{1}$ Interaction research city and business density for ICT product clustering is significant at $15 \%$ significance level.

Number of observations 377 . Significance is $* 0.1 \%$. $* * 0.05 \%$ and $* * * 0.01 \%$. Dependent variables: ICT content clustering (specifications 1 and 3) ; ICT product clustering (specifications 2 and 4). Standard errors clustered by city are in parenthesis. Country and year dummies are suppressed to save space. Non-linearities are incorporated. F-test for a joint significance of reform dimensions both in levels and squared was implemented and supported non-linear specification of country level variables Source: Authors calculation based on Eurostat (2012), Doing Business Statistics World Bank (2012).

Table 4: Cities and countries included in this study

\begin{tabular}{|c|c|}
\hline Cities & Country \\
\hline Wien & Austria \\
\hline Helsinki, Kernel Helsinki, Oulu, Tampere, Turku, Uppsala & Finland \\
\hline $\begin{array}{l}\text { Aix-en-Provence, Ajaccio, Amiens, Besancon, Bordeaux, Caen, Clermont-Ferrand, Dijon, } \\
\text { Grenoble, Le Havre, Lens - Lievin, Lille, Limoges, Lyon, Marseille, Metz, Montpellier, Nancy, } \\
\text { Nantes, Nice, Poitiers, Rennes, Rouen, Saint Denis, Saint-Etienne, Strasbourg, Toulouse }\end{array}$ & France \\
\hline Budapest, Debrecen, Gyor, Miskolc, Nyiregyhaza, Pecs, Szeged & Hungary \\
\hline $\begin{array}{l}\text { Ancona, Aquila, Bari, Bologna, Brescia, Cagliari, Campobasso, Caserta, Catania, Catanzaro, } \\
\text { Cremona, Firenze, Foggia, Genova, Milano, Modena, Napoli, Padova, } \\
\text { Palermo, Perugia, Pescara, Potenza, Reggio di Calabria, Roma, Salerno, Sassari, } \\
\text { Taranto, Torino, Trento, Trieste, Venezia, Verona }\end{array}$ & Italy \\
\hline Kaunas, Panevezys, Vilnius & Lithuania \\
\hline Luxembourg city & Luxembourg \\
\hline Liepaja, Riga & Latvia \\
\hline Antwerpen, Brugge, Bruxelles, Charleroi, Gent, Liege, Namur & Belgium \\
\hline $\begin{array}{l}\text { Almere, Amsterdam, Apeldoorn, Arnhem, Breda, Eindhoven, Enschede, Groningen, Heerlen, } \\
\text { Leeuwarden, Nijmegen, Rotterdam, Tilburg, Utrecht, s-Gravenhage }\end{array}$ & Netherlands \\
\hline Bergen, Kristiansand, Oslo, Stavanger, Tromso, Trondheim & Norway \\
\hline Aveiro, Braga, Coimbra, Ponta Delgada, Porto, Setubal & Portugal \\
\hline Goteborg, Jonkoping, Kernel Stockholm, Linkoping, Malmo, Orebro, Stockholm & Sweden \\
\hline Ljubljana, Maribor, Banska Bystrica, Bratislava, Kosice, Nitra, Presov, Trencin, Trnava, Zilina & Slovakia \\
\hline Ljubljana & Slovenia \\
\hline Burgas, Pleven, Plovdiv, Ruse, Sofia, Stara Zagora, Varna, Vidin & Bulgaria \\
\hline $\begin{array}{l}\text { Aberdeen, Belfast, Birmingham, Bradford, Bristol, Cambridge, Cardiff, Coventry, Edinburgh, } \\
\text { Glasgow, Glasgow, Kingston-upon-Hull, Leeds, Leicester, London, } \\
\text { Manchester, Newcastle upon Tyne, Nottingham, Portsmouth, Sheffield, Stevenage, Stoke-on- } \\
\text { trent, Wirral, Wolverhampton, Wrexham }\end{array}$ & UK \\
\hline $\begin{array}{l}\text { Augsburg, Berlin, Bielefeld, Bochum, Bonn, Bremen, Darmstadt, Dortmund, Dresden, } \\
\text { Dusseldorf, Erfurt, Essen, Frankfurt, Frankfurt-Oder, Freiburg im Breisgau, } \\
\text { Gottingen, Halle an der Saale, Hamburg, Hannover, Karlsruhe, Kiel, Koblenz, Koln, } \\
\text { Leipzig, Magdeburg, Mainz, Monchengladbach, Mulheim ad Ruhr, Munchen, Nurnberg, } \\
\text { Potsdam, Regensburg, Saarbrucken, Schwerin, Stuttgart, Trier, Weimar, } \\
\text { Wiesbaden }\end{array}$ & Germany \\
\hline Aalborg, Aarhus, Kobenhavn, Odense & Denmark \\
\hline
\end{tabular}


Tallinn, Tartu

Estonia

Alicante, Badajoz, Barcelona, Bilbao, Cordoba, Gijon, Hospitalet de Llobregat, Logrono, Madrid, Malaga, Santiago de Compostela, Sevilla, Valencia, Vigo, Vitoria/Gasteiz

Brno, Ostrava, Plzen, Praha, Usti nad Labem

Spain

Czech Rep

Appendix A: Distribution of an average number of ICT content and ICT product manufacturers per 1000 firms registered in countries (2004-2009)

\begin{tabular}{|c|c|c|c|}
\hline Country & Obs. & $\begin{array}{c}\text { Average number of ICT content } \\
\text { firms per 1000 firms }\end{array}$ & $\begin{array}{c}\text { Average number of ICT product } \\
\text { firms per 1000 firms }\end{array}$ \\
\hline Austria & 1 & 2.00 & 87.90 \\
\hline Belgium & 14 & 1.04 & 83.43 \\
\hline Bulgaria & 8 & 3.38 & 5.68 \\
\hline Czech Republic & 5 & 29.12 & 488.16 \\
\hline Germany & 46 & 11.52 & 74.88 \\
\hline Denmark & 4 & 16.25 & 583.85 \\
\hline Estonia & 6 & 4.32 & 52.30 \\
\hline Spain & 16 & 2.94 & 14.57 \\
\hline Finland & 13 & 3.38 & 66.03 \\
\hline France & 53 & 4.62 & 97.62 \\
\hline Hungary & 14 & 4.33 & 49.79 \\
\hline Italy & 65 & 3.81 & 60.72 \\
\hline Lithuania & 3 & 3.73 & 50.10 \\
\hline Luxembourg & 1 & 0.20 & 125.50 \\
\hline Latvia & 4 & 0.92 & 25.33 \\
\hline Netherlands & 25 & 13.10 & 44.08 \\
\hline Norway & 18 & 1.37 & 94.41 \\
\hline Portugal & 6 & 0.85 & 22.02 \\
\hline Sweden & 13 & 1.78 & 100.25 \\
\hline Slovenia & 6 & 7.37 & 136.98 \\
\hline Slovakia & 14 & 5.96 & 102.32 \\
\hline United Kingdom & 42 & 4.42 & 106.13 \\
\hline & & & \\
\hline
\end{tabular}

